\title{
Beyond the bench
}

\author{
Joshua Lederberg's latest honor, the Presidential Medal of Freedom Award, recognized not only his many \\ scientific accomplishments but those that benefited society as well.
}

L

ast December, Joshua Lederberg received the Presidential Medal of Freedom Award. This was the latest addition to Lederberg's large collection of awards and honors, which has included the Nobel Prize in 1958, the US National Medal of Science in 1989, the Institute of Medicine Medal in 2002 and election into the US National Academy of Sciences and the Royal Society of London.

Lederberg's contributions to science were recognized early in his career: he was 33 when he received the Nobel Prize in Physiology or Medicine, along with Edward L. Tatum and George W. Beadle, for their "discoveries concerning genetic recombination and the organization of the genetic material of bacteria" - namely, bacterial conjugation. Lederberg and co-workers also discovered the process of bacterial transduction. This body of work (including the invention of replica plating) was a cornerstone in the foundation of molecular genetics.

His curiosity led him to scientific exploits even beyond our planet. Concerned about the potentially disastrous biological consequences of space exploration - the contamination of extraterrestrial environments with Earth microbes carried by spacecrafts-he campaigned for a cautionary protocol of sterilization of spacecrafts before launch. He coined the term 'exobiology' and made sure that probing for traces of life on Mars was among the objectives of the US space program. He also participated in the design and construction of fully automated laboratory equipment to examine Martian soil samples by mass spectrometry in loco.

The Medal of Freedom bestowed on Joshua Lederberg is not 'just another award': it is the highest civilian honor given by the US government, established by President John F. Kennedy in 1963, to be presented to "any person who has made an especially meritorious contribution to the security or national interests of the United States, world peace, or cultural or other significant public and private endeavors." In presenting the award, President George W. Bush said, "For his brilliant career, his high ethical standards, and his many contributions to our country, the United States thanks Joshua Lederberg."

The other recipients of the Medal of Freedom in 2006 included educators, historians, journalists and public servants, people who committed themselves to improving other people's lives. A quick glance of the list of awardees from previous years reveals architects, economists, judges, civil rights leaders, environmental activists, philanthropists, athletes, actors, musicians, writers - a cross-section of those who shape and inspire society. Among them, only a handful of scientists were found deserving of such recognition, largely because of their contributions to public health. It makes one wonder why so few scientists are recognized for their contributions to society, given the great impact that science has on everyone's life.
The answer may reside in what is remarkable in Joshua Lederberg's career, besides his scientific accomplishments: his dedication to public service. He has advised both governmental and nongovernmental organizations on public policy, contributing his expertise and point of view to issues of mental health, biological arms control and environmental protection. He has worked against the proliferation of biological weapons and advised the government on preparedness against biological attacks. Finally, he made science more accessible to the general public by writing a weekly column on science and society for the Washington Post from 1966 to 1971.

Lederberg has been hailed for being a public scientist, for "crossing the divisions between science, society and politics." Why don't more scientists do the same? One might argue that with a Nobel Prize in hand he can afford to use his time for other activities. That may be true: between writing grants and papers, mentoring students and postdocs, administrative and teaching duties, scientific conferences and participation in study sections, there is not much time left for most scientists to do much of anything else. Add to that the dwindling funding situation and consequent tougher competition, and a scientist's time is really stretched thin.

But time spent in public service is time well spent, since the ultimate mission of science is to serve society. Knowledge (a goal in itself) and the technological benefits that come from applying it are the fruits of our work as scientists. The gap between scientists and the general public is unfortunate, because the public are ultimately paying most of the bills for research, and the politicians who represent them decide how much of their money goes into science. Thus, it is essential that the public at large and the politicians be more aware of what we scientists do: it will fight public mistrust of scientists in general, which has been fed by instances of fraud and financial conflicts of interest and by thorny ethical issues such as embryonic stem cell research. In this context, education and public outreach are important forms of service that immediately benefit the public in ways that will translate back to the scientific community. Though there are programs aimed at such outreach, scientists could certainly be more involved.

A detailed account of Lederberg's contributions to science and the public interest can be found at the US National Library of Medicine Profiles in Science (http://profiles.nlm.nih.gov/BB). The formal citation accompanying the Medal of Freedom says, "The US honors Joshua Lederberg for his achievements in scientific discovery and his commitment to improving the lives of others." Not a bad example to try to follow. 